\title{
AN ADAPTATION OF THE NEUMAN SYSTEMS MODEL TO THE CARE OF THE HOSPITALIZED PRESCHOOL CHILD
}

\author{
J.P. Orr
}

\section{INTRODUCTION}

A study was undertaken wherein a nursing model was proposed to facilitate the provision of holistic care for the hospitalized preschool child. This was done in an attempt to ensure that the physical, emotional, social and intellectual needs of the young child could be all incorporated into his nursing care.

Kershaw and Salvage (1986: xii) state that any model of nursing should be fluid and dynamic so that it may be adapted or modified to meet a specific need. The Neuman Systems Model was selected as a suitable framework within which to organize the nursing care of the hospitalized preschool child as its emphasis on both system and stress theory allowed for a meaningful interpretation of the problems of hospitalization. In addition it had potential for unifying the physical care of the child with other aspects of his development.

The Neuman Systems Model, as appears in Neuman (1989: 26), subsequently was adapted in an attempt to provide multifaceted care for the hospitalized preschool child. Castledine maintains "... that to adapt or modify something implies some form of change in quality, so it fits more easily that which was intended" (Castledine 1986: 64). In this respect the Neuman Systems Model was suitable as it facilitated an understanding of the interrelationship of the various factors which make the experience of hospitalization stressful for the young child. By beginning with the child and his family and progressing to the environment surrounding them, the interdependence of all the factors required for the restoration or maintenance of health was made apparent.

\begin{abstract}
This article describes an adaptation of the Neuman Systems Model to the care of the hospitalized preschool child. This was done to unite the physical care of the hospitalized preschool child with other aspects of his development and to describe the causes and prevention of stresses of hospitalization for this child.
\end{abstract}

\section{Opsomming}

Hierdie artikel beskryf ' $n$ aanpassing van die Neuman Systems Model vir die sorg van die gehospitaliseerde voorskoolse kind. Dit is onderneem om die fisiese sorg van die gehospitaliseerde kleuter met ander aspekte van sy ontwikkeling te integreer, asook om die oorsake en voorkoming van die stres van hospitalisasie te beskryf.

\section{DESCRIPTION OF THE NEUMAN SYSTEMS MODEL}

The Neuman Systems Model emphasises "wholeness... thus avoiding the fragmented and isolated nature of past functioning in nursing" (Neuman 1982: 1). The basic tenets of this model view man as an open system in interaction with his environment and incorporate a total person approach with the view to assist a person "... to attain a maximal level of health through the use of purposeful interventions aimed toward strengthening adaptive mechanisms, decreasing stress factors, or decreasing adverse conditions" (Neuman 1982: 118). The health of an individual is considered in this model to be determined by his reaction to stress. Stressors in the environment may be intrapersonal, interpersonal or extrapersonal. Nursing is considered to be a cooperative activity during which the nurse assists the client to cope with stress at either a primary, secondary or tertiary level so that the client may return to a state of optimum stability and health (Hawkins 1983: 31).

Basic assumptions regarding the Neuman Systems Model

The following basic assumptions are considered to be inherent in this model (Neuman 1982: 12-14; Thibodeau 1983: 117-118; Whall 1983: 203; Neuman 1989: 25; Cross 1990: 261-262):

- The client may be an individual, a group such as a family, or a community;

- Each client is an open system that is dynamically and continually interacting with and reacting to stressors in the environment;

- The individual client in a state of wellness or illness is a dynamic composite of the interrelationship of physiological, psychological, sociocultural, developmental and spiritual variables which are always present;

- Although each client is unique, each client system is a combination of known characteristics contained within a basic core structure with a normal range of response;

- Stressors in the environment, which may be physiological, psychological or sociocultural, have the potential to disturb a client's health and stability; these may be intrapersonal, interpersonal or extrapersonal in origin;

- The degree to which a client reacts to a stressor is determined by his defences and his personal perception of it;

- Each client develops a normal range of response to the environment which represents a dynamic state of 
adaptation. This range of response is called the normal line of defence or usual wellness/stability state;

- Each client has a flexible line of defence that constantly changes as a result of stressors; such flexibility cushions the client from stressors. The interrelationship of physiological, psychological, sociocultural, developmental and spiritual variables determine the nature and degree of reaction to a stressor;

- Each "client system" has a set of internal resistance factors which endeavour to stabilize the client and return him to his normal line of defence and which are known as lines of resistance;

- Reconstitution in response to a stressor results in the client achieving another (higher or lower) state of wellness than existed prior to the stress reaction;

- Primary prevention relates to the assessment and reduction of risk factors associated with environmental stressors;

- Secondary prevention refers to intervention after a reaction to stressors has occurred, so that their negative effects may be reduced;

- Tertiary prevention refers to that readjustment which is required to maintain stability.
BASIC ELEMENTS IN THE ADAPTATION OF THE NEUMAN SYSTEMS MODEL FOR THE PROVISION OF TOTAL CARE FOR THE HOSPITALIZED PRESCHOOL CHILD

The assumptions on which the adaptation of the Neuman Systems Model are based are deduced from those which appear in the previous section.

\section{The person receiving care}

In this model the person receiving care is the preschool child viewed within the context of his family. The "preschool child" refers to the child under the age of seven years and the terms "infant" and "toddler" are not specifically used for the younger child. This age group was selected as it is the period during which the child is most likely to be anxious and distressed by the unfamiliar environment, the threatening nature of medical procedures, separation from his parents and his inability to correctly perceive the passage of time. The child is the primary system of focus with other subsystems or suprasystems occurring in relation to him. Although the function of the nurse is to provide direct care to the child, she will, in addition, have to focus on all family members to assess the effect of the child's illness on them. According to Azarnoff \& Hardgrove (1981: 18) the treatment of sick children "... should take into account their physical and emotional environment ... [which includes their] ... relationships with their families".
Each child, as well as the members of his family, are considered to be in a state of dynamic interaction with, and reaction to, the stressors in the environment. The child is seen as an open system protected by certain defence mechanisms represented by a series of concentric rings; these protect him from stressors in the environment. Because of the age of the preschool child, his parents are seen to be one of the buffers or boundaries which protect him from environmental stressors and which serve to control the dynamic exchange between him and the environment. In addition to acting as a boundary, the parents and siblings can also be viewed as a suprasystem surrounding the child.

The individual child is considered to be an interrelationship of physiological, psychological, sociocultural, cognitive and spiritual variables which comprise subsystems within him. This deviates slightly from the Neuman Systems Model in that Neuman (1989) does not include a cognitive variable but incorporates it into the psychological variable. In this model adaptation, the developmental variable has been excluded as it appears to be inherent in the other variables. The variables are thus described as follows:

- the physiological variable incorporates the child's physical and biological structure and functioning;

- the psychological variable refers to those processes related to emotional

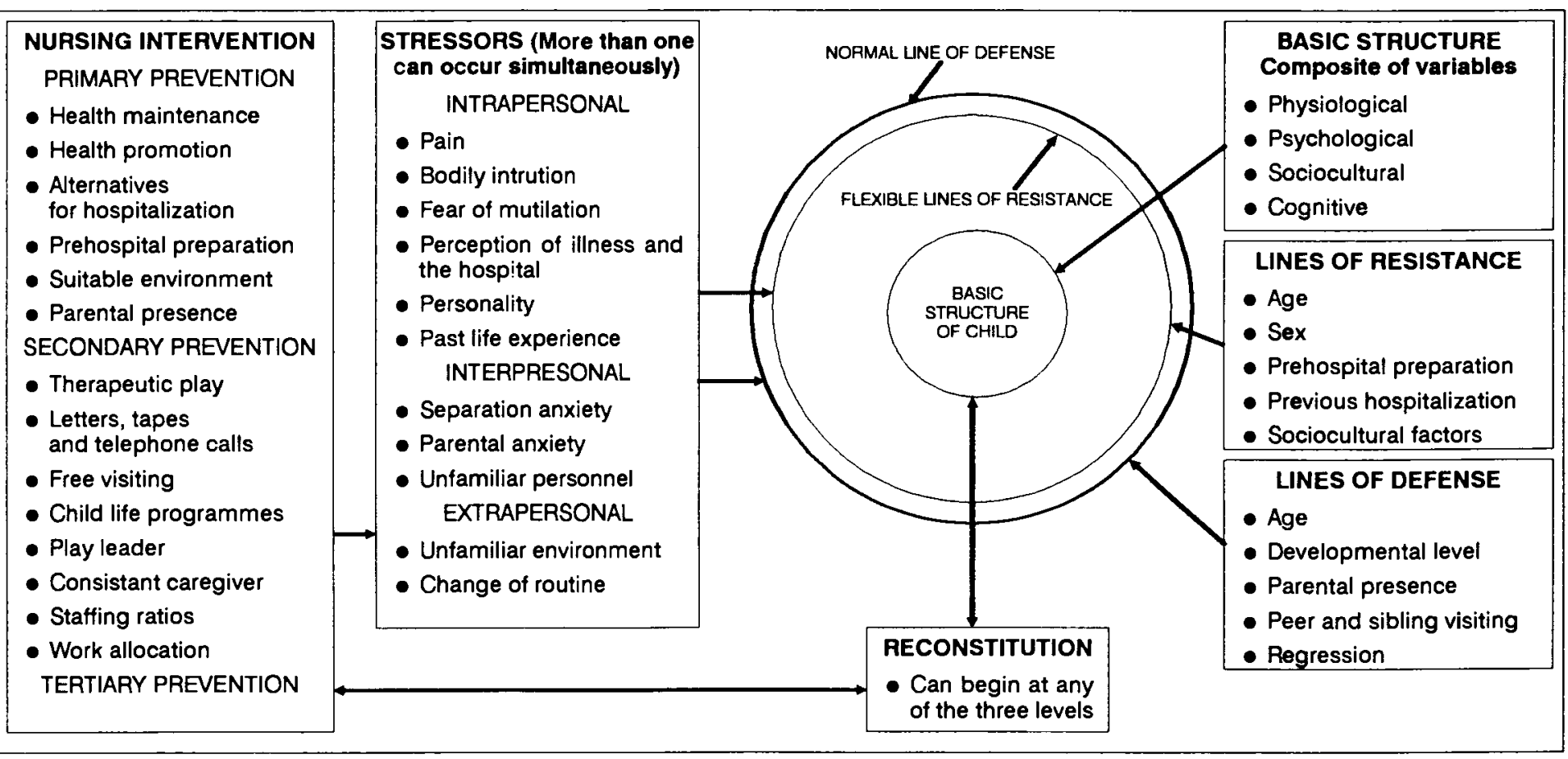


functioning and which include the ego and self concept;

- the sociocultural variable refers to those social and cultural factors which influence the life of the child and his interaction with others. The cultural background of the child and the life-style of his family will often determine his reaction to unfamiliar situations such as hospitalization. According to Walters (1983: 56) the nurse must guard against ethnocentricity and should consider the chent's cultural views of health and illness before attempting to plan or implement nursing care. She further states that "... open recognition and consideration for individual differences will help to foster interest, respect, and compliance" and avoiding cultural contradictions will eliminate confusion about different health practices (Walters 1983: 59).

- the cognitive variable involves the processes of thought, understanding and learning; and

- the spiritual variable refers to those factors of ethical, moral and religious origin which impinge on the preschool child through the influence of the values and beliefs of his family (Barry, 1989; Neuman, 1989). Many of the rituals practised at birth, such as circumcision and baptism, as well as dietary practices, restrictions on medical treatments, or beliefs regarding illness causation are linked to the spiritual variable and may have an effect on health.

The reaction of the child to a stressor is determined by his defences - which in Neuman's terminology are referred to as flexible lines of resistance, normal lines of defense and flexible lines of defence. For the purposes of this adapted model, only the flexible lines of resistance and normal lines of defence are used. Within the context of this topic a function was not found for the flexible lines of defence.

- The flexible lines of resistance change continually as a result of the interrelationship of the five previously mentioned variables making up the basic structure of the child. Factors like the age or sex of the child, his previous experience of hospitalization, his sociocultural background and his developmental or cognitive stage can all help to protect him from the stress of hospitalization.

- The normal line of defence is the child's normal range of responses to environmental factors. In terms of the hospitalized child this could be the presence of his parents in the hospital which buffer him from some of the stress experienced.

\section{Health definition}

In this adapted model, health is viewed as a state of balance between the person and his environment which permits optimal physiological, psychological, cognitive, sociocultural and spiritual functioning. The state of the child's health at any particular time is considered to be continually changing due to his adjustment to environmental stressors (Neuman 1989: 33).

\section{A description of the environment}

Neuman considers that the environment consists of both internal and external aspects in a continual state of flux. In addition, the external environment (or that milieu which surrounds the hospitalized child comprising the physical surroundings, emotional environment and human resources), is specifically emphasized. In Neuman terminology, stressors comprise the environment and these may be defined as "...tension producing stimuli or forces occurring within both the internal and external environmental boundaries of the client" (Neuman 1989: 70). Stressors can be classified as intrapersonal, interpersonal or extrapersonal. Each of these, as they affect the hospitalized preschool child, will be described.

Intrapersonal stressors arise from within the child and include factors such as pain, bodily intrusion, fear of mutilation, loss of self-control, the child's perception of illness and the effects of the child's personality and past life experiences. Parental intrapersonal stressors would include anxiety and guilt feelings while sibling stressors would be aspects like the fear of becoming ill, or the sibling's perception of his parents relationship to him and his response to the sick child's illness. If stressors which impinge on the family as a unit are considered, then intrafamily stressors would be all those individual interactions occurring among family members (Neuman 1983: 246).

- Interpersonal stressors arise from the interaction between the child and other individuals and include such factors as separation anxiety, parental anxiety and the unfamiliarity of the hospital personnel. For the parents or siblings, interpersonal stressors could include the child's illness which might result in the family being unable to function effectively, lack of information or the exclusion of the family from care of the sick child. Neuman considers interfamily stressors to be all those factors occurring between the family and the immediate environment such as interaction with other families, community groups or agencies (Neuman 1983: 246).

- Extrapersonal stressors originate from outside the individual and he has no specific control over these. In the hospital situation these stressors for the child could include the unfamiliar environment, the change of routine, sensory deprivation or overload, and a lack of play opportunities. For the parent of the hospitalized child extrapersonal stressors could include financial concerns and the unfamiliarity of the hospital environment and apparatus.

The goal of nursing and a description of those activities which comprise nursing

Neuman describes the major goal of nursing as "... helping stabilize both the individual and the family system, as clients, within their environment" (Neuman 1983: 253). This implies minimizing the factors which affect optimal system functioning and reducing the degree of reaction to a stressor by strengthening the defence systems and so ensuring system stability. Neuman defines the nursing component of her model as "... keeping the client system stable through accuracy both in the assessment of effects and possible effects of environmental stressors and in assisting client adjustments required for an optimal wellness level" (Neuman 1989: 34).

Nursing thus consists of intervention which occurs at the levels of primary, secondary and tertiary prevention. This is briefly described hereunder and dealt with in more detail in the next section.

- Primary prevention is initiated when a stressor is suspected or before any reaction has occurred. During this stage the child's normal line of defence or usual state of wellness is protected by preventing stress or reducing risk factors. In the model adaptation this could include health maintenance and promotion; the provision of alternatives for the hospital care of children; consideration being given to environmental factors; ensuring that children are not nursed in adult wards and prehospital preparation for both the child and parent. An additional factor involved in primary prevention 
is to avoid separating the child from his parents and to instead encourage them to remain with him as much as possible should hospitalization be inevitable.

- Secondary prevention is instituted in order to stabilize the child and strengthen his lines of resistance after stress symptoms have appeared. In terms of the hospitalized child this would involve providing him with opportunities to vent his stress by means of therapeutic play or other forms of crisis therapy. Free visiting by parents, siblings and peers should be encouraged. For the child who is separated from home, transitional objects, letters, audio tape-recordings and photographs could be utilized to maintain home ties and to decrease the separation anxiety. In addition, consistent caregivers should be provided to promote security, and attention should be given to staffing ratios and work allocation patterns to achieve this goal. In those circumstances where the nurse is not able to provide play opportunities, a child-life programme should be instituted or a playleader should be employed.

- Tertiary prevention assists the child to readapt so that a recurrence of the system disorganization is prevented and stability is regained. In terms of the hospitalized preschool child this would involve aspects such as parental and staff education. If the child is severely traumatized as a result of his hospitalization experience, then he should be referred for psychological or psychiatric counselling. For the parent, tertiary prevention could take the form of self-help groups and parental support groups.

\section{A DISCUSSION OF NURSING INTERVENTION AS IT HAS BEEN APPLIED IN THE ADAPTED NEUMAN SYSTEMS MODEL TO THE CARE OF THE HOSPITALIZED PRESCHOOL CHILD}

Nursing intervention can occur at three levels. The specific application of nursing intervention to the care of the hospitalized preschool child will be discussed hereunder:

\section{Primary prevention as intervention}

The goal of primary prevention is to avoid contact with a stressor or to strengthen the child's defence so that a stress reaction does not occur. During the primary prevention stage the risk is known. Primary prevention for the preschool child is seen to have a number of aspects:

- The provision of preventative and promotive health services in the community which could initially impact on the mother in the form of genetic counselling and antenatal services; later the baby and young child are helped to maintain or optimize health and to limit need for contact with the hospital environment. Such services would include, amongst others, adequate peri-natal and post-natal services as well as immunization, nutritional, dental, health screening and health education services.

- Alternative forms of health care are recommended which will incorporate the extension of community facilities and home-care programmes as these are often less stressful substitutes for hospital treatment (Dimock 1960:40; Hales-Tooke 1973: 30). The increased use of day clinics for minor surgical procedures or treatments could limit the child's length of exposure to a strange environment. Sinclair \& Whyte advocate the development of community paediatric nursing schemes to reduce the length of stay in hospital for most children and to prevent hospital admission completely for others. These schemes could "... provide back-up for short-stay surgery" as well as a specialist service to children with chronic or long-term illness (Sinclair \& Whyte 1987: 4). These paediatric community health nurse specialists, through their contributions to education, practice and research, would have the potential to profoundly transform the health and development of the children of Africa (Barnes 1987: ii). The extension of day surgery clinics together with the provision of a supportive paediatric community nursing service would have benefits for all involved. The nursing scheme could serve as a link between the home and the clinic and would be able to provide the necessary pre- and post-operative preparation, information and care required.

- Prehospital parental and child programmes should be initiated by nurses, preschool teachers, psychologists, social workers or other interested persons to help prepare the child and his family for an unexpected hospital admission. Although these would not be focused on a specific hospital or illness, they could familiarize the child with general aspects of hospitalization and the persons working within that environment. At this level the media (television, video-tapes and books), as well as hospital tours, puppet shows or fantasy play with medical equipment in the home or preschool environment could be profitably utilized (Plank, 1964; Whitson, 1972; Altshuler, 1974; Azarnoff \& Flegal, 1975; Galligan, 1975; Jolly, 1977; Fassler, 1978; Crocker, 1979; Van Huyssteen 1980; Schulz, Raschke, Dedrick \& Thompson, 1981; Vogel, 1981; Huth, 1983; Jalongo, 1983; Varni, 1983; Azarnoff, 1984; Trawick-Smith \& Thompson, 1984; Clarke, 1986; Gross, 1986; Alexander, 1988).

- Environmental alterations should be considered so that the hospital milieu becomes less hostile and threatening to the young child (Hunt, 1960; Shore, 1965; Lindheim, Glaser \& Coffin, 1972; Oremland \& Oremland, 1973; Hardgrove \& Dawson, 1976; Olds, 1978; Robinson \& Clarke, 1980; Jolly, 1981; Olds, 1981; Chan, 1986).

- Staff education in the form of in-service programmes should be initiated to educate all those working with children about the total needs of the hospitalized child (Robertson, 1970).

- Parental presence during the child's hospitalization should be encouraged to prevent the occurrence of separation anxiety (Bellack 1974). An infant should be provided with a mother-substitute if the mother does not room-in (Ziegler \& King, 1982; La Rossa \& Brown, 1982).

\section{Secondary prevention as intervention}

In the secondary prevention stage nursing intervention occurs to treat symptoms which have occurred and internal and external resources are used to reduce the reaction and to strengthen the lines of resistance.

In terms of the preschool child, one would assume this child had already had some contact with the health care system (doctors or specialized investigations) or was already hospitalized and as a consequence was showing some adverse reaction. The stages of the nursing process should be utilized to assess the situation, make a nursing diagnosis, plan for and then implement some form of nursing action and evaluate and record the outcome (Yura \& Walsh, 1973; Mauksch \& David, 1974; Ashworth, 1980; Griffith-Kenney \& Christensen, 1986). 
Secondary prevention for the hospitalized preschool child has the following possible components:

- Crisis therapy should be considered to allow the child to resolve his fears and conflicts. Possible interventions that could prove useful are therapeutic play (Green, 1974; Butler, Chapman \& Stuible, 1975; Smith, 1977; Clatworthy, 1978; Petrillo \& Sanger 1980; Clatworthy, 1981; Pillitteri, 1981; Meer, 1985); filmed modelling (Melamed \& Siegel, 1975; Melamed, Meyer, Gee \& Soule, 1976; Azarnoff \& Woody, 1981; Peterson \& Shigetomi, 1981); the mutual storytelling technique (Gardner, 1970; Becker, 1972); stress immunization (Hardgrove, 1977; Meng \& Zastowny, 1982; Poster, 1983; Sarafino, 1986; Smith, Goodman \& Ramsey, 1987) and sensation-orientated preparation (Johnson, Kirchoff \& Endress, 1976). With appropriate training it is possible for the nurse to initiate any of the above techniques with the child.

- Free visiting should be allowed and encouraged in any paediatric ward to help reduce the stress of hospitalization for the child, as well as his family. Hospital authorities should allow visiting by parents, siblings and peers (Stacey, Dearden, Pill \& Robinson, 1970; American Academy of Pediatrics, 1971; Jefferies, 1974; King \& Ziegler, 1981).

- Contact with home should be encouraged for those children whose family are not able to visit due to geographical distance or other factors. (Chadwick, Pflederer \& Ray, 1978; Marlow \& Redding, 1988).

- The child should be allowed to bring transitional objects from home and these could include any items that are "special" to the child like blankets, toys, dummies or any other object which provides security to the child. Parents should be discouraged from trying to wean their children from dummies or drinking bottles during this period. To help the child to deal with the fear of abandonment, parents should be advised to leave transitional objects from home, such as the mother's handbag or scarf, so that the child knows she will return.

- In order to reduce anxiety in the young child and to be able to provide the child with individualized attention, he should be exposed to as few strange people as possible. For this reason a consistent caregiver is recommended which will involve the "patient allocation" system being used instead of the "task allocation" system (Hales-Tooke, 1973; Weller, 1980; Pillitteri, 1981). In addition, there must be adequate staff provision so that the nurse is able to give sufficient attention to each child under her care (Cleary, 1979).

- In situations where the nurse is not able to provide play opportunities for her paediatric patients, the hospital authorities should consider instituting a child-life programme or employing a playleader who can provide adequate recreational and therapeutic play activities (Stacey et al., 1970; Azarnoff \& Flegal, 1975; Hart, 1976; Hall, 1977; Hall \& Stacey, 1979).

- The child should be helped to meet his needs for control by offering him choices, for example with foods or toys, whenever possible. The older preschool child could be allowed to participate in his own personal care or nursing treatments.

Additional strategies which may be used to allow the child to regain some control over what is happening to him include continuing with those rituals and routines to which the child is accustomed at home as well as allowing him as much physical activity and exploration of the environment as his condition permits. $\mathrm{He}$ should also be allowed to wear his own pyjamas.

- Parental participation in care should be encouraged, both in personal care activities as well as in providing comfort and support during medical and nursing procedures or treatments (Bellack, 1974). In order to promote an atmosphere conducive to mothering, privacy and a comfortable chair should be available at each bed or cot. If parents are not able to room-in with their child then they should be advised to be available at the child's normal bedtime as this is a time when the child is particularly vulnerable. The parents should be encouraged to continue with the child's usual bedtime rituals so that the unfamiliarity of the environment is reduced. Parents should also be given the opportunity to talk openly to staff about their child's illness so that the stress that they are experiencing is acknowledged.

- Children who are confined to bed must receive adequate sensory stimulation (Lindsay, 1981; Chaze \& Ludington-Hoe, 1984). Young children should be provided with opportunities for visual exploration (mobiles, mirrors, toys, pictures and books); tactile stimulation through cuddling, stroking and holding and auditory stimulation through talking and music. Physical mobility should be permitted provided there are no medical reasons to restrict this. If the child is being exposed to excessive stimulation then this should be decreased in whatever areas possible. Nursing care should be so organized that definite quiet periods are allowed for rest or sleep.

\section{Tertiary prevention as intervention}

Tertiary prevention is implemented when the child has regained some degree of system stability as a result of the secondary prevention measures that were instituted. The goal of tertiary prevention is to maintain reconstitution by preventing additional reactions to stressors or regression from the child's present level of stability. The ideal outcome of intervention at this stage is "... turning the stressful situation and the problem-solving activities into growth-producing experiences ... which ... build strength, confidence and coping capacity to handle future stresses or crises successfully and independently". To achieve this, tertiary prevention usually necessitates a team approach with other "helping professions" (Peachey 1981: 278).

Tertiary prevention as intervention, has been interpreted in terms of the hospitalized child, to have the following components:

- Staff education should be instituted at an in-service level to educate all staff members who have contact with the child regarding the stress to which he is exposed to in the hospital environment. These in-service programmes should include aspects like child communication, parent communication, preparation for medical and nursing procedures and how to include the family in the care of the ill child. These courses should stress that individualized and humanistic nursing care of children requires knowledge of current theories of child development, family development and the effects of hospitalization on children. Nurses working in paediatric units must be made to realize that the child should be emphasized rather than the attainment of psychomotor skills (Folan 1983: 208-215). 
- Staff communication in the hospital is important and regular meetings should be held to discuss those policies and procedures which impact negatively on the child's experience of hospitalization. In addition attempts should be made, on an interdisciplinary level, to discuss the creation or institution of programmes (preadmission or in-hospital) to alleviate the stress of hospitalization (Schreier 1980: 52).

- Parental education is important so that the parents are made aware of the possible symptoms of regression that the child might exhibit after his discharge from hospital. Parents should be advised to accept regression as a healthy reaction to stress and should be reassured that the child will return to normal if he is treated with consistency and love (Hymovich, 1976; Asen-Rudbarg Vardaro, 1978; Droske, 1978; Gelderblom, 1981; Vestal, 1981; Schepp, 1991). In addition, parents should be educated regarding techniques which they can use to assist the young child to cope with stress (Honig, 1986). Any nurse who is initiating a parental education session should consider the following factors: the cultural background of the parents, their fluency in the language of tuition, their previous level of knowledge, their anxiety level and the existence of any misconceptions regarding their child's illness or treatment.

- The nurse should refer the child to psychological or psychiatric counselling services should he show any serious behavioural disorders as a result of his hospitalization.

- Parents should be supported during their child's hospitalization and given the opportunity to express their needs and emotions. Parents should be referred to parental support groups and self-help groups who will help them to resolve problems when help is unavailable within the traditional health structures (Skovholt, 1974; Trainor, 1983; Marlow \& Redding, 1988). Likewise, help in the form of individual counselling or self-help groups should be obtained for any siblings who are experiencing stress so that their coping abilities are strengthened.

\section{CONCLUSION}

The manner in which a child copes with illness and hospitalization is significantly influenced by stressors which affect him in varying degrees, dependant upon factors such as his developmental level, age, sex, cognitive stage and family background. This adaptation of the Neuman Systems Model is one attempt to demonstrate how nursing interventions can be utilized to help reduce the intrapersonal, interpersonal and extrapersonal stressors that affect the hospitalized preschool child and his family.

\section{REFERENCES}

ALEXANDER, S. (1988). Puppets as a teaching tool. Nursing RSA, 3(9): 24-26.

ALTSHULER, A. (1974). Books that help children deal with a hospital experience. Rockville, MD: U.S. Department of Health, Education and Welfare.

\section{AMERICAN ACADEMY OF} PEDIATRICS. (1971). Care of children in hospitals. 2nd edition. Evanston, IL: American Academy of Pediatrics.

ASEN-RUDBARG VARDARO, J. (1978). Preadmission anxiety and mother-child relationships. Journal of the Association for the Care of Children in Hospitals, 7(2): 8-15.

ASHWORTH, P. (1980). Problems and solutions. Nursing Mirror. 151(12): 34-36.

AZARNOFF, P. and FLEGAL, S. (1975). A paediatric play program. Springfield, IL: Charles C. Thomas.

AZARNOFF, P. \& HARDGROVE, C. (Eds.) (1981). The family in child health care. New York: John Wiley \& Sons.

AZARNOFF, P. \& WOODY, P.D. (1981). Preparation of children for hospitalization in acute care hospitals in the United States. Pediatrics, 68(3): 361-368.

AZARNOFF, P. (1984). Preparing children for the stress of hospitalization. Resident \& Staff Physician, 30(4): 56-59.

BARNES, C.M. (Ed.) (1987). Recent advances in nursing: nursing care of children in health and illness. London: Churchill-Livingstone.

BARRY, P.D. (1989). Psychosocial nursing assessment and intervention: care of the physically ill person. 2nd edition. Philadelphia: Lippincott.
BEAL, J.A. (Ed.) (1983). Issues and advanced practice in paediatric nursing. Reston: Reston Publishing Company.

BECKER, R.D.C. (1972). Therapeutic approaches to psychopathological reactions to hospitalization International Journal of Child Psychotherapy, 1: 65-97.

BELLACK, J.P. (1974). Helping a child cope with the stress of injury. American Journal of Nursing, 74(8): 1491-1494.

BROWNING, M.H. \& MINEHAN, P.L. (1974). The nursing process in practice. New York: American Journal of Nursing Company.

BUTLER, A., CHAPMAN, J. \& STUIBLE, M. (1975). Child's play is therapy. Canadian Nurse, 71(12): 35-37.

CASTLEDINE, G. (1986). A stress adaptation model. In Kershaw, B. \& Salvage, J. (Eds.) Models for Nursing. New York: John Wiley.

CHADWICK, B.J., PFLEDERER, D. \& RAY, M.A. (1978). Maintaining the hospitalized child's home ties. American Journal of Nursing, 78(8): 1361-1362.

CHAN, J.M. (1986). Environmental considerations in promoting the adjustment of children to the health care setting. Interface, 11(2): 6-12.

CHAZE, B.A. \& LUDINGTON-HOE, S.M. (1984). Sensory stimulation in the NICU. American Journal of Nursing, 84(1): 68-71.

CLARKE, D.L. (1986). The value of play for convalescing children. In McKee, J.S. (Ed.) Play: Working partner of growth. Wheaton, MD: Association for Childhood Education International.

CLATWORTHY, S.M. (1978). The effect of therapeutic play on the anxiety behaviors of hospitalized children. D.Ed. thesis, Boston University School of Education.

CLATWORTHY, S.M. (1981). Therapeutic play: effects on hospitalized children. Journal of the Association for the Care of Children in Hospital, 9(4): 108-113.

CLEMENTS, I.W. \& ROBERTS, F.B. (Eds.) (1983). Family health: A theoretical approach to nursing care. New York: John Wiley. 
CROCKER, E. (1979). Hospital books for children. Canadian Nurse, 75(11): 33.

CROSS, J.R. (1990). Betty Neuman. In George, J.B. (Ed.) Nursing theories: The base for professional nursing practice. 3rd edition. Englewood Cliffs, NJ: Prentice Hall.

DIMOCK, H.G. (1960). The child in hospital: a study of his emotional and social well-being. Philadelphia: F.A. Davis.

DROSKE, S.C. (1978). Children's behavioral changes following hospitalization: have we prepared the parents? Journal of the Care of Children in Hospital, 7(2): 3-7.

FASSLER, J. (1978). Helping children cope. New York: Free Press.

FITZPATRICK, J.J. \& WHALL, A.L. (1983). Conceptual models of nursing: Analysis and application. Bowie, MD: R.J. Brady.

FOLAN, M.T. (1983). Development of teaching experiences that emphasize the child. In Beal, J.A. (Ed.) Issues and advanced practice in paediatric nursing. Reston: Reston Publishing Company.

GALLIGAN, A.C. (1975). Books for the hospitalized child. American Journal of Nursing, 75(12): 2164-2166.

GARDNER, R.A. (1970). The mutual storytelling technique: use in the treatment of a child with post-traumatic neurosis. American Journal of Psychotherapy, 24: 419-439.

GELDER BLOM, I.L. (1981). Die reaksies van ouers en kinders t.o.v. hospitalisasie en mediese behandeling. Geneeskunde, 23: 117-121.

GELLERT, E. (Ed.) (1978) Psychosocial aspects of paediatric care. New York: Grune \& Stratton.

GEORGE, J.B. (Ed.) (1990). Nursing theories: the base for professional nursing practice. 3rd edition. Englewood Cliffs, NJ: Prentice Hall.

GREEN, C.S. (1974). Understanding children's needs through therapeutic play. Nursing 74, 4(10): 31-32.

GRIFFITH-KENNEY, J.W. \& CHRISTENSEN, P.J. (1986). Nursing process: application of theories, frameworks and models. 2nd edition. St Louis: C.V. Mosby.

GROSS, S. (1986). Paediatric tours of hospitals: positive or negative? American Journal of Maternal-Child Nursing, 11(5): 336-338.
HALES-TOOKE, A. (1973). Children in hospital: the parents' view. London: Priory Press.

HALL, D.J. (1977). Social relations and innovation: Changing the state of play in hospitals. London: Routledge \& Kegan Paul.

HALL, D.J. \& STACEY, M. (1979). Beyond separation: Further studies of children in hospital. London: Routledge \& Kegan Paul.

HARDGROVE, C.B. \& DAWSON, R.B. (1976). Ideas, A to $Z$, for personalizing paediatric units. Nursing 76, 6(4): 57-65.

HARDGROVE, C. (1977). Emotional inoculation: the $3 \mathrm{R}$ 's of preparation. Journal of the Care of Children in Hospital, 5(4): 17-19.

HART, D. (1976). The role of the play leader in the hospital. Australasian Nurses Journal, 5(4): 30-32.

HAWKINS, J.W. (1983). Historical development of models of nursing practice. In Thibodeau, J.A. Nursing models: Analysis and evaluation. Belmont: Wadsworth Inc.

HONIG, A.S. (1986). Stress and coping in children. (Part 1). Young Children, 41(4): 51-63.

HONIG, A.S. (1986). Stress and coping in children. (Part 2). Young Children, 41(5): 47-59.

HUNT, W.D. (1960). Hospitals, clinics and health centres: An architectural record book. New York: McGraw Hill.

HUTH, M.M. (1983). Guidelines for conducting hospital tours with early school-age children. Paediatric Nursing, 9(6): 414-415 \& 430-431.

HYMOVICH, D.P. (1976). Parents of sick children: their needs and tasks. Paediatric Nursing, 2: 9-13.

JALONGO, M.R. (1983). Using crisis oriented books with young children. Young Children, 38(5): 29-36.

JEFFERIES, P.M. (1974). Free visiting for children. Paediatric Nursing Care. London: Nursing Times Publication.

JOHNSON, J.E., KIRCHHOFF, K.T. \& ENDRESS, M.P. (1976). Easing children's fright during health care procedures. American Journal of Maternal-Child Nursing, 1(4): 206-210.

JOLLY, J. (1977). How to be in hospital without being frightened. Nursing Times, 72(48): 1887-1888.
JOLLY, J. (1981). The other side of paediatrics. London: Macmillan.

KERSHAW, B. \& SALVAGE, J. (Eds.) (1986). Models for nursing. New York: John Wiley \& Sons.

KING, J. \& ZIEGLER, S. (1981). The effects of hospitalization on children's behaviour: a review of the literature. Journal of the Association for the Care of Children in Hospital, 10(1): 20-28.

LaROSSA, M.M. \& BROWN, J.V. (1982). Foster grandmothers in the premature nursery. American Journal of Nursing, 82(12): 1834-1835.

LINDHEIM, R. GLASER, H.H. \& COFFIN, C. (1972). Changing hospital environments for children. Cambridge, MA: Harvard University Press.

LINDSAY, K.E. (1981). The value of music for hospitalized infants. Journal of the Association for the Care of Children in Hospitals, 9(4): 104-107.

LOUIS, M. \& KOERTVELYESSY, A. (1989). The Neuman model in nursing research. In Neuman, B. The Neuman Systems Model. 2nd edition. Norwalk, CT: Appleton \& Lange.

MARLOW, D.R. \& REDDING B.A. (1988). Textbook of paediatric nursing. 6th edition. Philadelphia: W.B. Saunders.

MAUKSCH, I.G. \& DAVID, M.L. (1974). Prescription for survival. In Browning, M.H. \& Minehan, P.L. The nursing process in practice. New York: American Journal of Nursing Company.

McKEE, J.S. (Ed.) (1986). Play: working partner of growth. Wheaton, MD: Association for Childhood Education International.

MEER, P.A. (1985). Using play therapy in outpatient settings. American Journal of Maternal-Child Nursing, 10(6): 378-380.

MELAMED, B.G. \& SIEGEL, L.J. (1975). Reduction of anxiety in children facing hospitalization and surgery by use of filmed modelling. Journal of Consulting Clinical Psychology, 43(4): 511-521.

MELAMED, B.G., MEYER, R., GEE, C. \& SOULE, L. (1976). The influence of time and type of preparation on children's adjustment to hospitalization. Journal of Paediatric Psychology, 1(4): 31-37.

MENG, A.L. \& ZASTOWNY, T. (1982). Preparation for hospitalization: A stress inoculation training program 
for parents and children. American Journal of Maternal-Child Nursing, 11(2): 87-94.

NEUMAN, B. (1982). The Neuman Systems Model: Application to nursing education and practice. Norwalk, CT: Appleton-CenturyCrofts.

NEUMAN, B. (1983). Family intervention using the Betty Neuman Health-care Systems Model. In Clements, I.W. \& Roberts, F.B. Family health: A theoretical approach to nursing care. New York: John Wiley \& Sons.

NEUMAN, B. (1989). The Neuman Systems Model. 2nd edition. Norwalk, CT: Appleton-Century-Crofts.

OLDS, A.R. (1978). Psychological considerations in humanizing the physical environment of paediatric outpatient and hospital settings. In Gellert E. (Ed.) Psychosocial aspects of paediatric care. New York: Grune \& Stratton.

OLDS, A.R. (1981). Humanizing the paediatric hospital environment. Hospital Administration Currents, 25(1): 1-6.

OREMLAND, E.K. \& OREMLAND, J.D. (1973). The effects of hospitalization on children: models for their care. Springfield, IL: Charles C. Thomas.

PARKER, S.E. (1983). Paediatric care: a guide for patient education. Norwalk, CT: Appleton-Century-Crofts.

PEACHEY, C.R. (1981). Managing stress: family crisis intervention. In Tackett, J.J.M. \& Hunsberger, M. Family centered care of children and adolescents: nursing concepts in child health. Philadelphia: W.B. Saunders.

PETERSON, L. \& SHIGETOMI, C. (1981). The use of coping techniques to minimize the anxiety in hospitalized children. Behavior Therapy, 12: 1-14.

PETRILLO, M. \& SANGER, S. (1980). Emotional care of hospitalized children: an environmental approach. 2nd edition. Philadelphia: J.B. Lippincott.

PILLITTERI, A. (1981). Child health nursing: care of the growing family. 2nd edition. Boston: Little, Brown.

PLANK, E. (1964). Working with children in hospitals: a guide for the professional team. London: Tavistock.

POSTER, E. (1983). Stress immunization: techniques to help children cope with hospitalization.
American Journal of Maternal-Child Nursing, 12(1): 120-134.

ROBERTSON, J. (1970). Young children in hospital. London: Tavistock.

ROBINSON, G.C. \& CLARKE, H.F. (Eds.) (1980). The hospital care of children: a review of contemporary issues. New York: Oxford University Press.

SARAFINO, E.P. (1986). The fears of childhood: a guide to recognizing and reducing fearful states in children. New York: Human Sciences Press.

SCHEPP, K.G. (1991). Factors influencing the coping effort of mothers of hospitalized children. Nursing Research, 40(1): 42-46.

SCHREIER, A. (1980). Preparing young children for hospitalisation. Preschool Years, 10: 48-53.

SCHULZ, J.B., RASCHKE, D., DEDRICK, C \& THOMPSON, M. (1981). The effects of a preoperational puppet show on anxiety levels of hospitalized children. Journal of the Association for the Care of Children in Hospital, 9(4): 118-121.

SHORE, M.F. (Ed.) (1965). "Red is the colour of hurting": planning for children in the hospital. Betheseda, MA: National Institute of Mental Health.

SINCLAIR, H. \& WHYTE, D. (1987). Perspectives on community care for children. In Barnes, C.M. (Ed.) Recent advances in nursing: Nursing care of children in health and illness. London: Churchill-Livingstone.

SKOVHOLT, T.M. (1974). The client as helper: a means to promote psychological growth. Counselling Psychologist, 4(3): 58-64.

SMITH, L.F. (1977). An experiment with play therapy. American Journal of Nursing, 77(12): 1963-1965.

SMITH, M.J., GOODMAN, J.A. \& RAMSEY, N.L. (1987). Child and family: Concepts of nursing practice. 2nd edition. New York: McGraw Hill.

STACEY, M., DEARDEN, R., PILL, R. \& ROBINSON, D. (1970). Hospitals, children and their families. London: Routledge \& Kegan Paul.

TACKETT, J.J.M. \& HUNSBERGER, M. (1981). Family centered care of children and adolescents: nursing concepts in child health. Philadelphia: W.B. Saunders.

THIBODEAU, J.A. (1983). Nursing models: analysis and evaluation. Belmont: Wadsworth Inc.
TRAINOR, M.G. (1983). Self-Help groups as a resource for individual clients and families. In Clements, I.M. \& Roberts, F.B. (Eds.) Family health: a theoretical approach to nursing care. New York: John Wiley \& Sons.

TRAWICK-SMITH, J. \& THOMPSON, R.H. (1984). Preparing young children for hospitalization. Young Children, 39(5): 57-63.

VAN HUYSSTEEN, M. (1980). Die kind in die hospitaal: verpleegster praat en speel met hom! Curationis, 3(2): 16-19.

VARNI, J.W. (1983). Clinical behavioral pediatrics: An inter- disciplinary biobehavioral approach. New York: Pergamon.

VESTAL, K.W. (Ed.) (1981). Paediatric critical care nursing. New York: John Wiley.

VOGEL, J.B. (1981). Child life and play programs. In Vestal, K.W. (Ed.) Paediatric critical care nursing. New York: John Wiley \& Sons.

WALTERS, C.R. (1983). Cultural and environmental influences on health teaching. In Parker, S.E. Paediatric care: a guide for patient education. Norwalk, CT. Appleton-CenturyCrofts,

WELLER, B.F. (1980). Helping sick children play. London: Balliere Tindall.

WHALL, A.L. (1983). The Betty Neuman Health Care System Model. In Fitzpatrick, J.J. \& Whall, A.L. Conceptual models of nursing: analysis and application. Bowie, MD: R.J. Brady.

WHITSON, B.J. (1972). The puppet treatment in pediatrics. American Journal of Nursing, 72(9): 1612-1614.

YURA, H. \& WALSH, M.B. (1973). The nursing process: assessing, planning, implementing, evaluating. 2nd edition. New York: AppletonCentury-Crofts.

ZIEGLER, S. \& KING, J. (1982). Evaluating the observable effects of foster grandparents on hospitalized children. Public Health Reports, 97(6): 550-557.

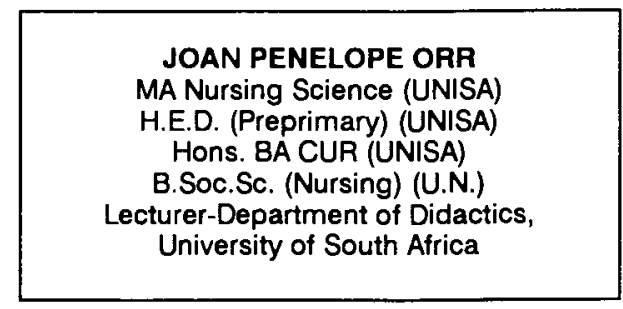

